\title{
MULTIVARIATE CLUSTERING OF VITICULTURAL TERROIRS IN THE DOURO WINEMAKING REGION
}

\section{CLASSIFICAÇÃO MULTIVARIADA DOS TERROIRS VITIVINÍCOLAS NA REGIÃO DEMARCADA DO DOURO}

\author{
Helder Fraga ${ }^{1 *}$; Ricardo Costa ${ }^{1}$, João A. Santos ${ }^{1}$ \\ ${ }^{1}$ Centre for the Research and Technology of Agro-Environmental and Biological Sciences, CITAB, Universidade de Trás-os-Montes e Alto \\ Douro, UTAD, 5000-801 Vila Real, Portugal \\ *corresponding author: Tel: +351259350389, email: hfraga@utad.pt
}

(Received 18.05.2017. Accepted 27.11.2017)

SUMMARY

The Douro Demarcated Region (DDR) is one of the most important winemaking regions in Portugal. Viticulture is historically and culturally tied to the DDR, having a strong impact on the local economy. This mountainous region, characterized by the steep slopes of the Douro Valley, provides a wide range of environmental characteristics for grapevine growth. Different climatic conditions, soil profiles, topography, grapevine varieties and management practices comprise the DDR terroir, resulting in the distinctiveness of the wines produced. In the present study, an assessment of the homogeneous zones of interest for viticultural activities is proposed for the DDR, by integrating different terroir elements (thermal, hydric, soils, topography and vegetation), using state-of-the-art high resolution datasets (1 km) and a large number of variables/indices. A multivariate zoning was carried out using a principal component analysis and a subsequent clustering methodology. A geospatial assessment of the terroir elements was also performed separately for each type of vegetation covering the DDR. The inter-connections of the different terroir elements that exist at a given location, were also innovatively assessed. The zoning may promote a more appropriate selection of vineyard sites, the selection of more locally-adapted varieties and rootstocks and the adoption of appropriate viticultural practices and management planning. After assessing the terroir conditions that exist at the current vineyard locations, possible expansion zones within the DDR were also evaluated. The present study may also be used as an archetypal methodology that can be applied to other winemaking regions worldwide.

\section{RESUMO}

A Região Demarcada do Douro (RDD) é uma das regiões vitivinícolas mais importantes de Portugal. A viticultura está historicamente e culturalmente ligada à RDD, tendo uma importância vital para a economia local. Esta região montanhosa, caracterizada pelas encostas íngremes do vale do Douro, proporciona uma ampla gama de características edafoclimáticas para o crescimento da vinha. Diferentes condições climáticas, perfis de solo, topografia, castas e práticas culturais fazem parte do terroir da RDD, resultando no carácter distintivo dos vinhos aí produzidos. No presente estudo, propõe-se uma avaliação de zonas homogéneas com interesse para as atividades vitivinícolas na RDD, integrando diferentes elementos do terroir (térmico, hídrico, solos, topografia e vegetação), utilizando-se conjuntos de dados de alta resolução (1 km) e um elevado número de variáveis/índices. Foi realizada uma zonagem multivariada com recurso à análise em componentes principais e a uma metodologia de clustering. A avaliação geoespacial dos elementos do terroir foi também realizada separadamente para cada tipo de vegetação existente na RDD. As interconexões entre os diferentes elementos do terroir de um determinado local também foram avaliadas de forma inovadora. Esta zonagem poderá potenciar uma seleção mais adequada de áreas vitícolas, a seleção de castas e porta-enxertos mais adaptados ao local e a adoção de práticas vitivinícolas mais adequadas. Depois de avaliar as condições de terroir existentes em cada local, também foram avaliadas as possíveis zonas de expansão vitivinícola dentro da RDD. O presente estudo pode também ser utilizado como uma metodologia padrão para aplicação a outras regiões vinícolas no mundo.

Key words: grapevine, principal component analysis, viticultural zoning, integrated assessment, Douro Demarcated Region.

Palavras-chave: videira, análise em componentes principais, zonagem vitícola, avaliação integrada, Região Demarcada do Douro.

\section{INTRODUCTION}

For viticulture, identifying the uniqueness of the environmental characteristics within a given region is crucial to analyze the winemaking suitability and potential. This zoning assesses the most relevant viticultural characteristics in each winegrowing region, providing a basis for strategic vintage

142

This is an Open Access article distributed under the terms of the Creative Commons Attribution License

(http://creativecommons.org/licenses/by/4.0), which permits unrestricted use, distribution, and reproduction in any medium, provided the original work is properly cited. 
planning (Jones, 2006; Clingeleffer, 2014; Costantini et al., 2016). The regional climate, soil properties, topography, varieties (biodiversity) and management practices of any given winemaking regions are usually described by the terroir concept (OIV, 2010). Although this term also includes other more broad aspects, signifying the distinctiveness and origin of the wines (e.g. branding, wine type and landscape), grapevine yields and berry quality attributes are usually linked to the abovementioned terroir characteristics.

Climate is the main driver for grapevine development and growth (Keller, 2010). Sunlight, heat and water demands influence grapevine yields and are responsible for a balanced grape ripening (e.g. Bindi et al., 1996; Jones and Davis, 2000; Camps and Ramos, 2012; Fraga et al., 2015). Soil is another important terroir element, crucial for water and nutrient uptake, which may also influence berry quality attributes (Morlat and Jacquet, 2003; Renouf et al., 2010). The topographic elements represent yet another key factor that influences viticultural and oenological characteristics of a given region. Amongst the most important topographic elements for viticulture are elevation, slope and solar exposure (Nascimbene et al., 2013; Yau et al., 2013). Additionally, vegetation type (grapevine cultivars, cover crops, intercrops and mixed vegetation systems) and management practices are also important terroir composing elements (Böhm, 2010).

The Douro Demarcated Region (DDR) is one of the oldest regulated winemaking regions in the world, famous for its Port Wine and other high-quality wines (Oliveira et al., 2005; Magalhães, 2008; Cunha and Richter, 2016; Fraga and Santos, 2017). The DDR spans over 250,000 ha in the Douro valley (Figure 1). It is one of the most important winemaking regions in Portugal, accounting for approximately $20 \%$ of the country's vineyard area and wine production (IVV, 2015). The terroir characteristics of the DDR are indeed unique and are not commonly found in other regions. Apart from vineyards, which is the main regional crop (over 20\% of the total area), forestry systems occupy nearly $50 \%$ of the area, followed by pastures (20\%), fruit trees (mostly dry fruits, $~ 5 \%$ ) and olive trees ( 5\%) (EEA, 2002).

Classified as Word Heritage by the UNESCO since 2001, for its natural resources and unique vineyard landscape, it is one of the most important mountainous viticultural regions in the world. The complex topography requires vineyards to be grown mostly on hillsides, requiring large human resources. The varieties planted are mostly autochthonous/native to the country, such as 'Touriga Nacional' or
'Touriga Franca'. The Mediterranean-like climatic conditions are particularly noticeable in this region, with an annual precipitation ranging from 400 to 900 $\mathrm{mm}$ (30\% from April to September, gradually decreasing eastwards), and annual mean temperatures varying from 12 to $16^{\circ} \mathrm{C}$.

Given the distinctness of the DDR, it is important to define its terroir characteristics in a thorough integrated approach. Several studies have addressed the terroir characteristics of a given winemaking region (Storchi et al., 2005; Jones, 2006; Carey et al., 2008; Clingeleffer, 2014; Costantini et al., 2016; Moral et al., 2016). However, for the DDR, few studies have been devoted to this assessment. Given the Mediterranean-type climatic characteristics and the complex topography of the DDR, very high resolution zoning data is required for a better understanding of the interactions and synergies among the different terroir elements. Similar terroir conditions across the regions are likely not only to produce grapes and wines with analogous characteristics, but also to enable crop management planning. Due to its high socioeconomic significance, vineyards are occupying increasing areas within the region. As such, it also becomes important to assess zones with high viticultural potential that are currently used for other less profitable crops, such as annual field crops, pastures and fruit trees (Figure 1a). Furthermore, climate change is projected to have strong negative impacts on both yields and quality of the wines produced in the DDR (Fraga et al., 2016a). A high resolution viticultural zoning of the DDR may allow developing adaptation measures against the projected warming and drying trends (Jones and Alves, 2012; Cunha and Richter, 2016; Fraga et al., 2016a,b). The present study aims to develop a multivariate zoning approach, through a holistic integration of the main terroir elements, herein illustratively applied to the DDR. A similar methodology can be conducted in other viticultural regions worldwide.

\section{MATERIAL AND METHODS}

\section{Terroir elements}

In the present study, five terroir elements were selected for analysis: (i) thermal conditions; (ii) hydric conditions; (iii) soils; (iv) topography; (v) vegetation dynamics (phenology and vigor/greenness). These elements were selected for their direct influence on grapevine growth and wine characteristics. The first two elements (thermal and hydric conditions) are strongly connected with grapevine yield and wine quality attributes (Agosta et 
al., 2012; Camps and Ramos, 2012; Kizildeniz et al., 2015). Grapevines require optimum temperatures and sufficient solar radiation throughout its growth cycle (Failla et al., 2004; Sadras and Moran, 2013). Furthermore, water availability is crucial during certain stages of grapevine development (Tramontini et al., 2013; Permanhani et al., 2016; Fraga et al., 2018), while excessive dryness may lead to detrimental water stress impacts (Pavlousek, 2011; Webb et al., 2012).

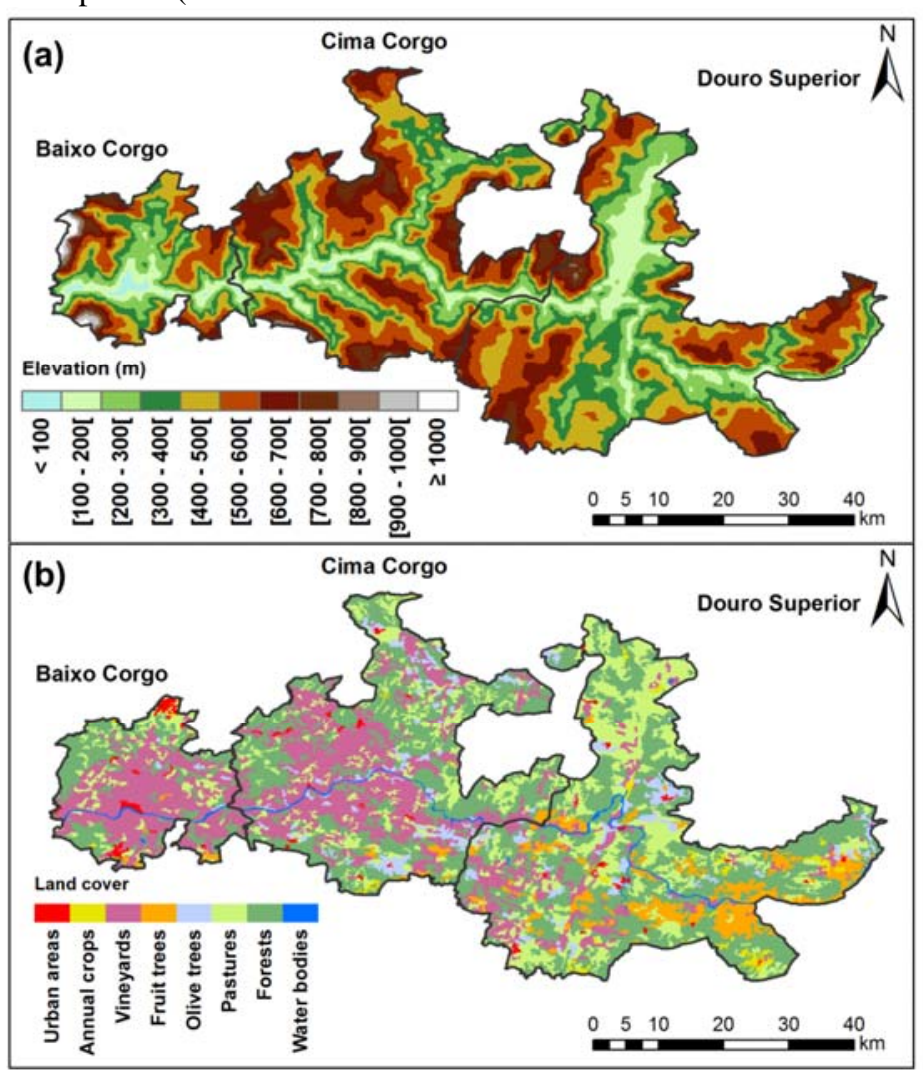

Figure 1. (a) Digital elevation model of the Douro Demarcated Region (DDR). (b) Land cover classification in the DDR, according to the CORINE land cover map. The three sub-regions of the DDR, Baixo Corgo (BC), Cima Corgo (CC) and Douro Superior (DS), are also outlined.

(a) Modelo digital de terreno da Região Demarcada do Douro (RDD). (b) Classificação da cobertura do solo na RDD, de acordo com o mapa de cobertura da CORINE. São também delineadas as três sub-regiões da RDD, Baixo Corgo (BC), Cima Corgo (CC) e Douro Superior (DS)

To assess these two terroir elements, high-resolution datasets, produced by the WorldClim project (Hijmans et al., 2005) at ca. $1 \mathrm{~km}$ spatial resolution, were used (Table I). The use of high resolution datasets have previously shown to be an important advance for viticultural zoning assessments (Hall and Jones, 2010; Jones et al., 2010; Anderson et al., 2012). For the thermal conditions, the following variables were assessed: annual, seasonal (DJF: December-January-February, MAM: March-AprilMay, JJA: June-July-August, SON: SeptemberOctober-November) and growing season (AprilOctober) minimum, maximum and mean temperatures; Cool night index (CI; Tonietto, 1999) from Fraga et al. (2014b); Growing degree-day (GDD; Winkler, 1974) from Fraga et al. (2014b); Thermicity index (TI; Rivas-Martínez and RivasSaenz, 2011) from Costa et al. (2017). For the hydric conditions, the following variables were selected: annual, seasonal (DJF, MAM, JJA, SON) and growing season (April-October) precipitation totals; Aridity index (AI; Rivas-Martínez and Rivas-Saenz, 2011) from Costa et al. (2017); Dryness index (DI; Tonietto and Carbonneau, 2004) from Fraga et al. (2014b). 
Table I

Selected variables used in the clustering approach in the each group

Variáveis utilizadas na metodologia de clustering em cada grupo

\begin{tabular}{|c|c|c|}
\hline Thermal variables & Acronym & Dataset \\
\hline Annual mean temperature $\left({ }^{\circ} \mathrm{C}\right)$ & TGann & \multirow{17}{*}{ 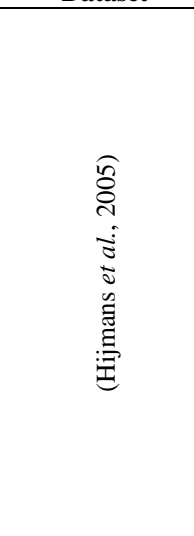 } \\
\hline Winter mean temperature $\left({ }^{\circ} \mathrm{C}\right)$ & TGdjf & \\
\hline Spring mean temperature $\left({ }^{\circ} \mathrm{C}\right)$ & TGmam & \\
\hline Summer mean temperature $\left({ }^{\circ} \mathrm{C}\right)$ & TGjja & \\
\hline Autumn mean temperature $\left({ }^{\circ} \mathrm{C}\right)$ & TGson & \\
\hline Growing season mean temperature $\left({ }^{\circ} \mathrm{C}\right)$ & TGgseas & \\
\hline Winter maximum temperature $\left({ }^{\circ} \mathrm{C}\right)$ & TXdjf & \\
\hline Spring maximum temperature $\left({ }^{\circ} \mathrm{C}\right)$ & TXmam & \\
\hline Summer maximum temperature $\left({ }^{\circ} \mathrm{C}\right)$ & TXjja & \\
\hline Autumn maximum temperature $\left({ }^{\circ} \mathrm{C}\right)$ & TXson & \\
\hline Winter minimum temperature $\left({ }^{\circ} \mathrm{C}\right)$ & TNdjf & \\
\hline Spring minimum temperature $\left({ }^{\circ} \mathrm{C}\right)$ & TNmam & \\
\hline Summer minimum temperature $\left({ }^{\circ} \mathrm{C}\right)$ & TNjja & \\
\hline Autumn minimum temperature $\left({ }^{\circ} \mathrm{C}\right)$ & TNson & \\
\hline Cool night index $\left({ }^{\circ} \mathrm{C}\right)$ (Tonietto, 1999) & $\mathrm{CI}$ & \\
\hline Growing degree-day $\left(\mathrm{C}^{\circ}\right)$ (Winkler, 1974) & GDD & \\
\hline Thermicity index (Rivas-Martínez and Rivas-Saenz, 2011) & TI & \\
\hline \multicolumn{3}{|l|}{ Hydric variables } \\
\hline Annual precipitation sum (mm) & Pann & \multirow{8}{*}{ 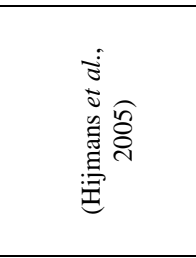 } \\
\hline Winter precipitation sum (mm) & Pdjf & \\
\hline Spring precipitation sum (mm) & Pmam & \\
\hline Summer precipitation sum (mm) & Pjja & \\
\hline Autumn precipitation sum (mm) & Pson & \\
\hline Growing season precipitation sum (mm) & Pgseas & \\
\hline Aridity index (Rivas-Martínez and Rivas-Saenz, 2011) & AI & \\
\hline Dryness index (mm) (Tonietto and Carbonneau, 2004) & DI & \\
\hline \multicolumn{3}{|l|}{ Soil variables } \\
\hline Bulk density $\left(\mathrm{kg} \mathrm{dm}^{-3}\right)$ & BulkDens & \\
\hline Clay content (\%) & Clay & $\stackrel{\infty}{\infty}$ \\
\hline $\mathrm{pH}(-\log (\mathrm{H}+))$ & $\mathrm{pH}$ & ษิธิ \\
\hline Salinity (dS/m) & Salinity & 胥 \\
\hline Sand content (\%) & Sand & $\sum 0$ \\
\hline Gravel content (\%) & Gravel & 崩号 \\
\hline Silt content (\%) & Silt & $\llbracket$ के \\
\hline Organic content (\%) & OC & 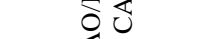 \\
\hline Total exchangeable bases $\left(\mathrm{cmol} \mathrm{kg}^{-1}\right)$ & TEB & $\underset{\mathbb{1}}{\mathbb{1}}$ \\
\hline Sodicity (\%) & ESP & \\
\hline Water table depth (m) & WTD & (Fan et al., 2013) \\
\hline \multicolumn{3}{|l|}{ Topography variables } \\
\hline Elevation (m) & Elev & \multirow{3}{*}{ 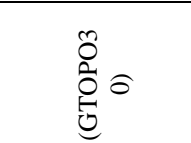 } \\
\hline Solar Exposure (hours) & SolarExp & \\
\hline Slope $\left(^{\circ}\right)$ & Slope & \\
\hline \multicolumn{3}{|l|}{ Vegetation variables } \\
\hline Budburst mean date (Julian day) & BUD & \multirow{4}{*}{ 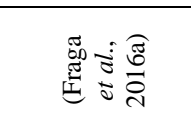 } \\
\hline Flowering mean date (Julian day) & FLO & \\
\hline Veraison mean date (Julian day) & VER & \\
\hline Harvest mean date (Julian day) & HAR & \\
\hline NDVI annual mean & NDVI & \multirow{5}{*}{ 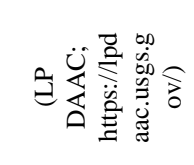 } \\
\hline NDVI winter mean & NDVIdjf & \\
\hline NDVI spring mean & NDVImam & \\
\hline NDVI summer mean & NDVIjja & \\
\hline NDVI autumn mean & NDVIson & \\
\hline
\end{tabular}

Soil characteristics were retrieved from the Harmonized World Soil Database (HWSD; FAO/IIASA/ISRIC/ISSCAS/JRC, 2012). HWSD soil properties were originally mapped at a 1:1,000,000 scale and are available at a resolution of $\sim 1 \mathrm{~km}$ (Table I). The selected variables were: Bulk density $\left(\mathrm{kg} / \mathrm{dm}^{3}\right)$; Clay content (\%); $\mathrm{pH}(-\log (\mathrm{H}+))$; Salinity (dS/m); Sand content (\%); Gravel content (\%); Silt content (\%); Organic content (\%); Total exchangeable bases $(\mathrm{cmol} / \mathrm{kg})$ and Sodicity (\%). Additionally, water table depth, retrieved from Fan et al. (2013), was also included in the analysis. 
A fourth set of variables was chosen to characterize the topography of the DDR, including elevation (m), slope $\left(^{\circ}\right.$ ) and solar exposure (number of hours of sun, excluding clouds). Elevation was retrieved from a digital elevation model, DEM (GTOPO30). Slope and solar exposure (photoperiod) were calculated from the DEM dataset using geographical information systems - ArcGIS (version 10.3.1) Spatial Analyst Tool.

A fifth set of variables was included to take into account the effect of vegetation growth and grapevine phenology. The Normalized Difference Vegetation Index (NDVI) was used for the analysis of the vegetative growth. NDVI takes into account the difference between near-infrared and red reflectances, providing a measure of vegetation greenness, where higher NDVI corresponds to higher vegetation greenness (Holm et al., 1987; Roderick et al., 1996; Huete et al., 2002). Applied to viticulture, spectral vegetation indices may assist management activities (Johnson et al., 2003; Fraga et al., 2014a) and have shown links to production and wine attributes (Johnson et al., 2001; Usha and Singh, 2013). In the present study, NDVI from the Moderate Resolution Imaging Spectroradiometer (MODIS) is obtained from the National Aeronautics and Space Administration (NASA) Land Processes Distributed Active Archive Center (LP DAAC; https://lpdaac.usgs.gov/). Two tiles covering all of Portugal (h17v04, h17v05) are retrieved, at a $1 \mathrm{~km}$ spatial resolution and on a 16-day temporal resolution, from 2000 to 2015. Furthermore, a set of maps containing the Julian dates of the main grapevine phenological timings (budburst, flowering, veraison and harvest) were also included as variables in the vegetation dynamics set. This data, which has been previously validated, was obtained from Fraga et al. (2016a).

Principal component analysis and clustering methodology

The delineation of homogeneous zones in the DDR was carried out using a principal component analysis (PCA) and a subsequent k-means clustering methodology, using MATLAB (version R2017a). Variables of each of the five terroir elements (thermal, hydric, soils, topography and vegetation) were first normalized by the corresponding mean prior to PCA, as variables have different physical units, also warranting equal weighting in clustering. PCA was used herein as a method to reduce the number of variables (over 40 variables for all terroir elements; Table I) to retain for subsequent clustering (k-means on the subspace of the leading orthogonal modes). After a preliminary sensitivity analysis, the leading two components (PC1 and PC2) of each terroir element were retained, in all cases cumulatively explaining much of the variance. By retaining only the leading two components, most of the variability in the initial variables is retained, while the dimension of the subsequent clustering is significantly lowered. Including additional components was also tested, though the analysis was not significantly improved at the expanse of a larger number of variables and less statistically robust results. The number of resulting clusters was tested and four clusters were eventually selected for each element. The selection of the number of clusters, though subjective (different number of clusters were also tested), was found to be a balanced compromise solution for capturing the different conditions within the DDR. In fact, a lower number (two or three clusters) is not able to entirely retain the diversity of the region, while a larger number would produce artificial sub-regions. Finally, the resulting clusters were mapped, corresponding to the viticultural terroirs in the DDR at ca. $1 \mathrm{~km}$ spatial resolution (total of $39101 \mathrm{~km}$ grid-cells).

\section{Relationships between the different terroir elements}

Following the maps of the clusters for each terroir element, their integrated assessment is performed. For this purpose, the highest occurrence between clusters of different terroir elements at the same $1 \mathrm{~km}$ gridcell is determined. This assessment was done separately for each of the sub-regions within the DDR (Baixo Corgo: BC; Cima Corgo: CC and Douro Superior: DS). The frequencies of occurrence of each clusters/terroir element were also assessed separately by each land cover class, using the CORINE land cover classification (EEA, 2002) shown in Figure 1b.

\section{RESULTS}

\section{Clustering approach}

As previously mentioned, the leading two principal components of each terroir element were retained for clustering. Table II shows the percentage of variation explained by these components. Cumulatively, the explained variance of the first two PCs was over 93\% for the thermal, hydric and vegetation groups and over $66 \%$ for the soil and topography groups. The first principal component represents more than $90 \%$ of the total variance for the thermal and hydric groups, while the second component represents much lower variance (3.5\% and $1.5 \%$, respectively). For the other three terroir elements, the first PC, while still explaining large fractions of variance, showed 
comparatively low values (soil: $44.9 \%$; topography; 34.7\%; vegetation: 62.8\%), while the second PC now acquires higher relative relevance. For these terroir elements, the spatial organization of the region in near-homogeneous areas is much less marked than for the thermal, hydric and vegetation groups, thus explaining the overall lower fractions of represented variance.

\section{Table II}

Variance represented by the first two principal components (PC1 and PC2) for each class, as well as the corresponding cumulative variance (sum of PC1 and PC2)

Variância explicada pelas duas primeiras componentes principais (PC1 e PC2) para cada classe, bem como a variância cumulativa correspondente (soma da PC1 e PC2)

\begin{tabular}{lccc}
\hline $\begin{array}{l}\text { Terroir } \\
\text { elements }\end{array}$ & $\begin{array}{c}\text { PC1 } \\
\text { Variance }\end{array}$ & $\begin{array}{c}\text { PC2 } \\
\text { Variance }\end{array}$ & $\begin{array}{c}\text { Cumulative } \\
\text { Variance }\end{array}$ \\
\hline Thermal & $94.5 \%$ & $3.5 \%$ & $98 \%$ \\
Hydric & $97.7 \%$ & $1.5 \%$ & $99 \%$ \\
Soil & $44.9 \%$ & $20.6 \%$ & $66 \%$ \\
Topography & $34.7 \%$ & $34.3 \%$ & $69 \%$ \\
Vegetation & $62.8 \%$ & $30.2 \%$ & $93 \%$ \\
\hline
\end{tabular}

A description of the four resulting clusters of each terroir element is provided in Table III. While the description of the thermal, hydric, topography and vegetation clusters are self-explanatory, the soil clusters correspond to the underlining 'soil unit name' from FAO (Food and Agriculture Organization of the United Nations) in the original soil dataset (FAO/IIASA/ISRIC/ISSCAS/JRC, 2012). Therefore, the nomenclature used in the HSWD was kept. Regarding the thermal clusters (Fig.2a), a clear distinction is evident in all the corresponding variables, with minimum temperature in the winter playing a key role for the zoning. Also for the hydric conditions (Figure 2c), a strong variable differentiation is apparent, being DI the leading variable. For the soil clustering (Figure 2e), some of the base variables have a more decisive role in zoning. Luvisols have higher gravel levels, Humic Cambisols have higher total exchangeable bases, Eutric/Dystric Cambisols show sand content and higher exchangeable sodium and Dystric Regosols have higher levels of organic matter. Regarding topography (Figure 2g), the description of the clusters is directly based on the weight of each of the three base variables. For the vegetation clustering (Figure 2i), NDVI acquires a more important role for zoning, particularly its summer values.
Table III

Description of the clusters for each terroir element

Descrição dos clusters para cada elemento do terroir

\begin{tabular}{|c|c|c|c|c|}
\hline \multirow{2}{*}{$\begin{array}{l}\text { Terroir } \\
\text { elements }\end{array}$} & \multicolumn{4}{|c|}{ Clusters } \\
\hline & 1 & 2 & 3 & 4 \\
\hline Thermal & Cool & $\begin{array}{c}\text { Moderat } \\
\text { e cool }\end{array}$ & $\begin{array}{l}\text { Moderate } \\
\text { warm }\end{array}$ & Warm \\
\hline Hydric & Wet & $\begin{array}{c}\text { Moderat } \\
\text { e wet }\end{array}$ & $\begin{array}{c}\text { Moderate } \\
\text { dry }\end{array}$ & Dry \\
\hline Soil & Luvisol & $\begin{array}{c}\text { Humic } \\
\text { cambisol }\end{array}$ & $\begin{array}{c}\text { Eutric/Dystri } \\
\text { c cambisol }\end{array}$ & $\begin{array}{l}\text { Dystric } \\
\text { regosol }\end{array}$ \\
\hline Topography & $\begin{array}{l}\text { High } \\
\text { elev. } \\
\text { Low } \\
\text { solar } \\
\text { exp. }\end{array}$ & $\begin{array}{l}\text { High } \\
\text { elev. } \\
\text { Low } \\
\text { slopes }\end{array}$ & $\begin{array}{l}\text { Low elev. } \\
\text { High slopes }\end{array}$ & $\begin{array}{c}\text { Low elev. } \\
\text { High } \\
\text { solar exp. }\end{array}$ \\
\hline Vegetation & $\begin{array}{l}\text { Early } \\
\text { phen. } \\
\text { High } \\
\text { green. }\end{array}$ & $\begin{array}{l}\text { Early } \\
\text { phen. } \\
\text { Low } \\
\text { green. }\end{array}$ & $\begin{array}{l}\text { Late phen. } \\
\text { Low green. }\end{array}$ & $\begin{array}{l}\text { Late } \\
\text { phen. } \\
\text { High } \\
\text { green. }\end{array}$ \\
\hline
\end{tabular}

\section{Spatial homogeneity in the DDR}

After processing data from each of the terroir elements, a preliminary zoning of the DDR was achieved (Figure 2). Different homogeneous areas were established for each of the five terroir elements. The cooler (thermal cluster 1; henceforth Thermal-1) and moderate cooler zones (Thermal-2) are located in the outer/higher elevation areas of the DDR, while the moderate warm (Thermal-3) and warm (Thermal-4) zones are located in the inner/lower elevation areas (Figure 2b). For the whole DDR, the cluster with the highest frequency is Thermal-2, followed by Thermal-3 (Table IV). The DDR is primarily characterized by moderately wet/wet (Hydric2/Hydric-1) conditions in the western and central areas (BC and CC), and moderately dry/dry (Hydric$3 /$ Hydric-4) conditions in the east (DS) (Figure 2d). The Hydric-2 cluster has the highest occurrence (34\%; Table IV). Regarding the soils of the DDR (Figure 2f), most of the region corresponds to the Soil-3 cluster: Dystric Regosols (63\%), while other clusters occur significantly less. Concerning topography, there is a strong association between high elevations, lower solar exposures and lower slopes (Topography-1 and -2, respectively) and between low elevations, high solar exposures and high slopes (Topography-3 and -4, respectively). The predominant cluster in the DDR is Topography-4 (33\%) (Table IV). For the vegetation clusters, a clear distinction between early phenology (Vegetation-1 and -2), in the eastern areas, and late phenology (Vegetation-3 and -4), in the west, is apparent. Higher greenness tends to occur in the higher elevation outer areas, while low greenness occurs in the inner areas 
of the DDR. The predominant cluster is Vegetation-2: $\quad$ early phenology and low greenness.

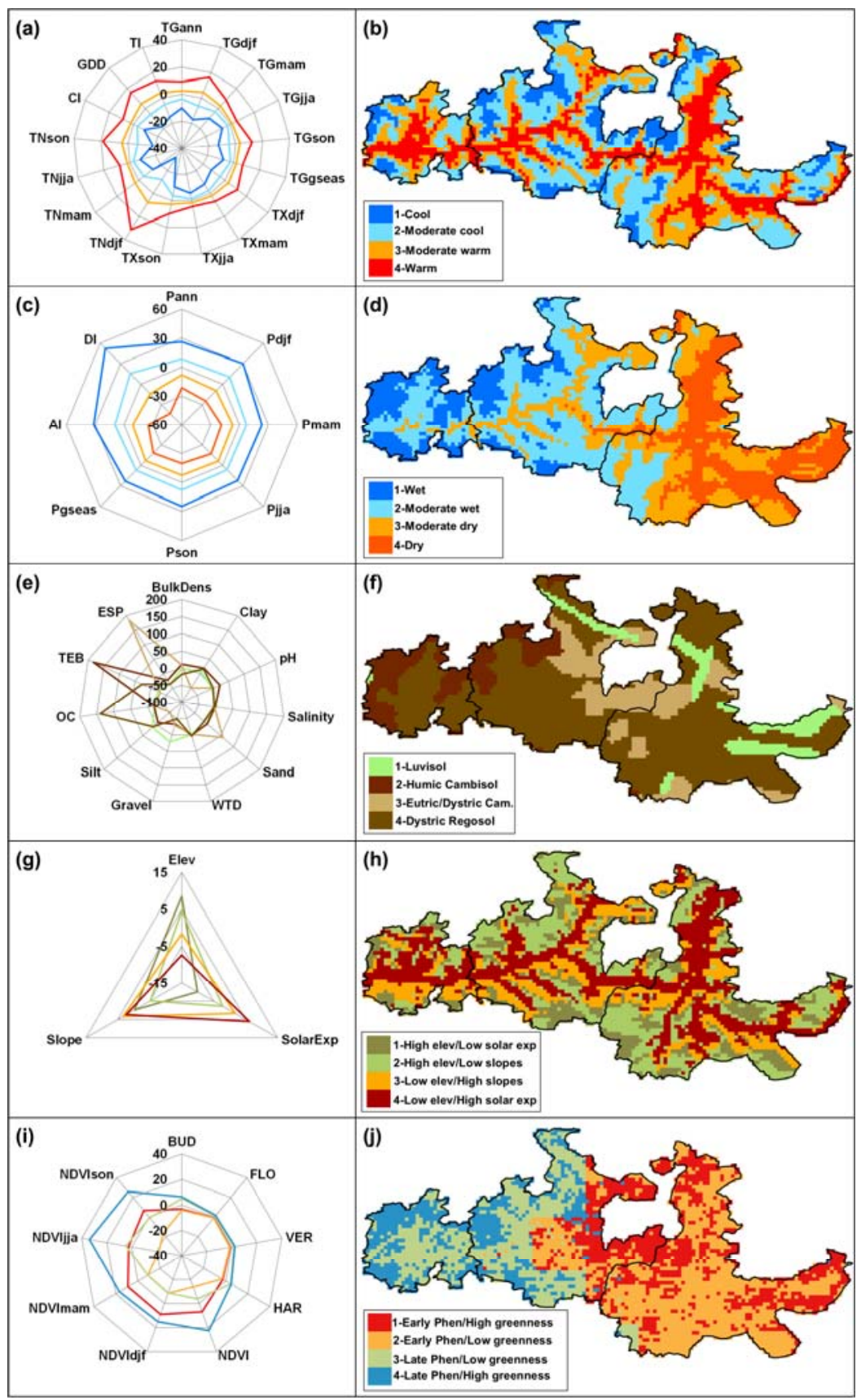

Figure 2. Radar chart with the normalized values of the variables used in the clustering methodology: (a, b) thermal; (c, d) hydric; (e, f) soils; (g, h) topography; (i, j) vegetation dynamics. Geographical representation of the clusters of each of the five terroir elements in the Douro Demarcated Region.

Diagrama de radar com os valores normalizados das variáveis utilizadas na metodologia de clustering: $(a, b)$ térmico; (C, d) hídrico; (E, f) solos; $(G, h)$ topografia; $(I, j)$ dinâmica da vegetação. Representação geográfica dos agrupamentos de cada um dos cinco elementos do terroir na Região Demarcada do Douro. 
Table IV

Percentage of each cluster occurrence in the Douro Demarcated Region (DDR). Grey shaded values indicate the highest cluster occurrence for each class

Percentagem de ocorrência de cada cluster na Região Demarcada do Douro (DDR). Valores em cinza indicam a maior ocorrência em cada classe

\begin{tabular}{lcccc}
\hline \multirow{2}{*}{$\begin{array}{l}\text { Terroir } \\
\text { elements }\end{array}$} & \multicolumn{4}{c}{ Clusters } \\
\cline { 2 - 5 } & $\mathbf{1}$ & $\mathbf{2}$ & $\mathbf{3}$ & $\mathbf{4}$ \\
\hline Thermal & $15 \%$ & $\mathbf{3 3 \%}$ & $30 \%$ & $22 \%$ \\
Hydric & $15 \%$ & $\mathbf{3 4 \%}$ & $29 \%$ & $22 \%$ \\
Soil & $9 \%$ & $12 \%$ & $16 \%$ & $\mathbf{6 3 \%}$ \\
Topography & $18 \%$ & $28 \%$ & $21 \%$ & $\mathbf{3 3 \%}$ \\
Vegetation & $26 \%$ & $\mathbf{3 5 \%}$ & $22 \%$ & $17 \%$ \\
\hline
\end{tabular}

\section{Integrated sub-regional terroir assessment}

The relationships between clusters of the different terroir elements were also performed on a subregional level (for BC, CC and DS). The highest association between clusters is shown in Figure 3. In all sub-regions Dystric Regosols dominate the associations between soils and other terroir elements. For the BC sub-region (Figure 3a), the moderately cool and the wet areas are strongly associated. Warm areas are associated with low elevations/high solar exposures and late phenology/low greenness. Wet areas are also tied to late phenology/high greenness and humic cambisols. In this sub-region, moderate wet areas are associated with low elevations/high solar exposures. In the CC sub-region, moderate cool and moderate wet areas are highly associated, being also connected to high elevation areas/low slopes and late phenology/low greenness. In the DS sub-region, moderate warm areas show links to early phenology/low greenness, while warm dry areas with low elevations and high solar exposures largely overlap.

\section{Land cover types}

A geospatial assessment of the terroir elements was also performed for each type of vegetation covering the DDR (Figure 4). Vineyards tend to be equally distributed in moderately cool (Thermal-2), moderately warm (Thermal-3) and warm zones (Thermal-4), and in moderately wet areas (Hydric-2). Dystric Regosols are the dominant soil type not only for this crop (Soil-4), but also for all the other vegetation types, since it is a regionally predominant soil type. Vineyards at low elevations and high solar exposures dominate the topography of the DDR (Topography-4). This crop is usually located in low greenness and late phenology zones (Vegetation-3). Comparing the terroir elements of other vegetation types, it is clear that olive trees tend to be located in areas that show very similar characteristics to vineyard locations, with correlation coefficient $r=0.72$ (Table V). Pasture locations in the DDR also reveal some similarities to vineyard locations, but to a lesser extent $(r=0.64)$. The areas that provide fewer similarities to the current vineyard locations are those devoted to annual crops ( $\mathrm{r}=0.13$ ), mostly due to hydric conditions in which they are currently grown (dryer lands).

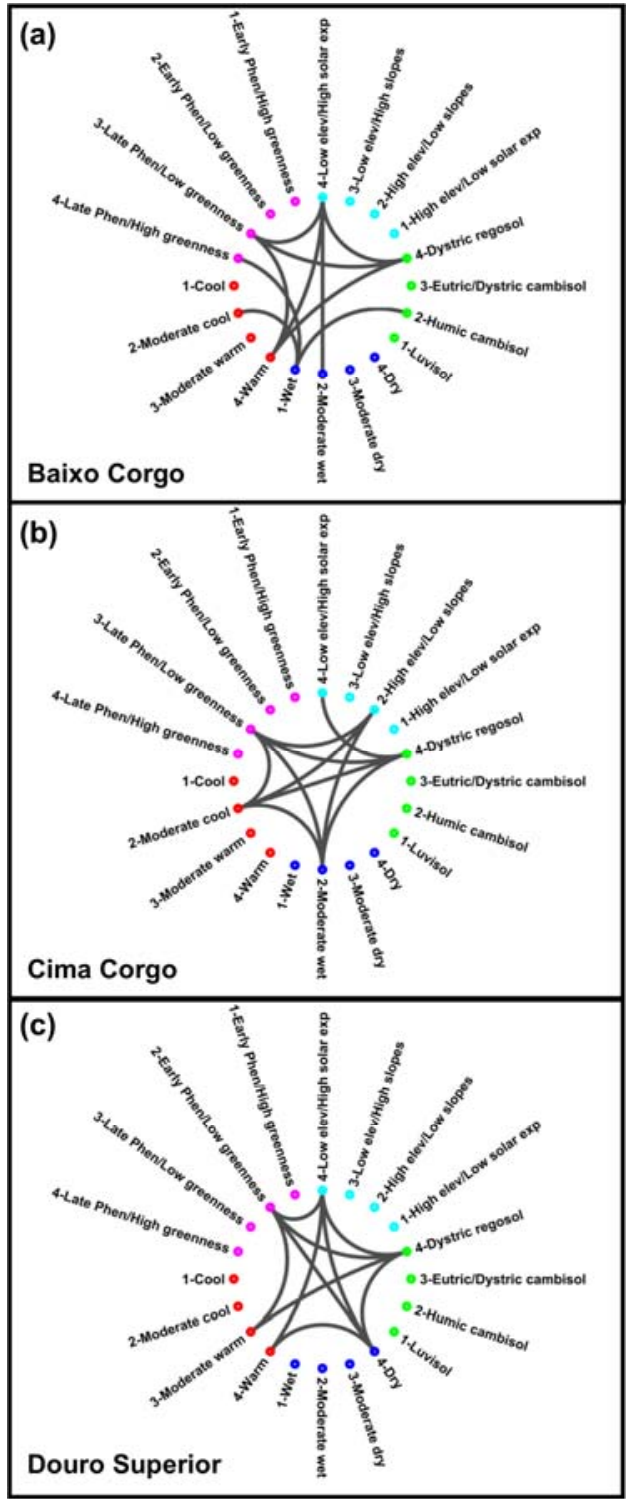

Figure 3. Chart representing the relationships between clusters of the different terroir elements. Only the highest association inside each sub-region is plotted: (a) Baixo Corgo (BC); (b) Cima Corgo (CC) and (c) Douro Superior (DS).

\footnotetext{
Relações entre os clusters dos diferentes elementos do terroir. Apenas a maior associação dentro de cada sub-região é representada: (a) Baixo Corgo (BC); B) Cima Corgo (CC) e (c) Douro Superior (DS).
} 
Table V

Pearson product-moment correlation coefficients between the different cluster occurrences of each land cover class in the Douro Demarcated Region (DDR)

Coeficientes de correlação de Pearson entre as diferentes ocorrências de clusters de cada classe de cobertura do solo na Região Demarcada do Douro (DDR)

\begin{tabular}{l|cccccc}
\hline & Vineyards & Annual crops & Fruit trees & Olive trees & Pastures & Forests \\
\hline Vineyards & & & & & \\
Annual crops & 0.13 & & & & \\
Fruit trees & 0.40 & 0.51 & & & \\
Olive trees & 0.72 & 0.41 & 0.85 & & \\
Pastures & 0.64 & 0.69 & 0.78 & 0.86 & \\
Forests & 0.44 & 0.37 & 0.50 & 0.66 & 0.76 \\
\hline
\end{tabular}

\begin{tabular}{|c|c|c|c|c|c|c|}
\hline & & 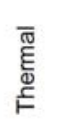 & $\begin{array}{l}\text { 음 } \\
\text { ำ }\end{array}$ & $\frac{\infty}{\bar{D}}$ & 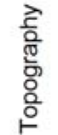 & 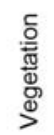 \\
\hline \multirow{4}{*}{ 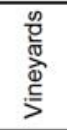 } & 1 & $6 \%$ & $17 \%$ & $4 \%$ & $13 \%$ & $7 \%$ \\
\hline & 2 & $31 \%$ & $53 \%$ & $14 \%$ & $24 \%$ & $30 \%$ \\
\hline & 3 & $32 \%$ & $23 \%$ & $11 \%$ & $23 \%$ & $51 \%$ \\
\hline & 4 & $31 \%$ & $7 \%$ & $71 \%$ & $40 \%$ & $12 \%$ \\
\hline \multirow{4}{*}{ 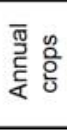 } & 1 & $18 \%$ & $9 \%$ & $20 \%$ & $49 \%$ & $7 \%$ \\
\hline & 2 & $58 \%$ & $4 \%$ & $4 \%$ & $44 \%$ & $84 \%$ \\
\hline & 3 & $18 \%$ & $58 \%$ & $24 \%$ & $0 \%$ & $7 \%$ \\
\hline & 4 & $7 \%$ & $29 \%$ & $51 \%$ & $7 \%$ & $2 \%$ \\
\hline \multirow{4}{*}{ 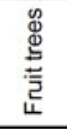 } & 1 & $5 \%$ & $5 \%$ & $18 \%$ & $15 \%$ & $27 \%$ \\
\hline & 2 & $27 \%$ & $11 \%$ & $1 \%$ & $18 \%$ & $64 \%$ \\
\hline & 3 & $35 \%$ & $25 \%$ & $8 \%$ & $28 \%$ & $7 \%$ \\
\hline & 4 & $33 \%$ & $59 \%$ & $72 \%$ & $40 \%$ & $2 \%$ \\
\hline \multirow{4}{*}{ 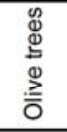 } & 1 & $6 \%$ & $1 \%$ & $10 \%$ & $14 \%$ & $26 \%$ \\
\hline & 2 & $28 \%$ & $34 \%$ & $1 \%$ & $16 \%$ & $45 \%$ \\
\hline & 3 & $32 \%$ & $36 \%$ & $15 \%$ & $30 \%$ & $19 \%$ \\
\hline & 4 & $34 \%$ & $29 \%$ & $73 \%$ & $40 \%$ & $9 \%$ \\
\hline \multirow{4}{*}{ 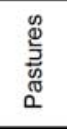 } & 1 & $15 \%$ & $11 \%$ & $11 \%$ & $19 \%$ & $23 \%$ \\
\hline & 2 & $35 \%$ & $30 \%$ & $11 \%$ & $35 \%$ & $49 \%$ \\
\hline & 3 & $29 \%$ & $33 \%$ & $16 \%$ & $13 \%$ & $13 \%$ \\
\hline & 4 & $21 \%$ & $26 \%$ & $62 \%$ & $33 \%$ & $15 \%$ \\
\hline \multirow{4}{*}{ 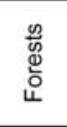 } & 1 & $23 \%$ & $20 \%$ & $9 \%$ & $20 \%$ & $39 \%$ \\
\hline & 2 & $36 \%$ & $28 \%$ & $15 \%$ & $30 \%$ & $24 \%$ \\
\hline & 3 & $28 \%$ & $31 \%$ & $20 \%$ & $23 \%$ & $10 \%$ \\
\hline & 4 & $13 \%$ & $21 \%$ & $56 \%$ & $27 \%$ & $26 \%$ \\
\hline
\end{tabular}

Figure 4. Frequency of occurrence (\%) of each cluster in each terroir element and for each land cover class.

Frequência de ocorrência (\%) de cada cluster em cada elemento do terroir e para cada classe de cobertura do solo.

\section{DISCUSSION AND CONCLUSIONS}

In the present study, an assessment of the homogeneous zones of interest for viticultural activities has been proposed for the DDR, by integrating different terroir elements, using state-ofthe-art high resolution datasets. Few studies have been dedicated to the assessment of the terroir composing elements over a whole region (Taylor,
2004; van Leeuwen et al., 2004; Carey et al., 2008; Yau et al., 2013; Costantini et al., 2016; Moral et al., 2016). However, the integration of all these factors, quantified by a large number of variables, into a high resolution viticultural zoning $(\sim 1 \mathrm{~km})$ in the DDR was not previously performed. The present study thereby significantly improves our understanding of the terroir spatial variability in the DDR.

Overall, four classes of each terroir element (thermal, hydric, soils, topography and vegetation dynamics) have been established, by applying a kmeans clustering on the subspace of the leading orthogonal modes. The delimited thermal classes may allow growers to select and grow grapevine varieties based on their optimum thermal requirements (Lopes et al., 2008; Alves et al., 2013). The hydric classes may also assist the selection of suitable rootstocks to improve plant water status (Pavlousek, 2011; Harbertson and Keller, 2012). These issues are particularly relevant taking into account the projected climate change impacts for the region, mainly the drying trend over the next decades (Fraga et al., 2016b; Santos et al., 2016). Furthermore, other terroir elements considered herein, such as slope degree, solar exposure, soil type and vegetation greenness, may assist growers in their management activities and vintage planning throughout the year (Johnson et al., 2001; Mackenzie and Christy, 2005; Judit et al., 2011; Bettiga et al., 2012; Nascimbene et al., 2013). The interconnections of the different terroir elements that exist at a given location was innovatively assessed. Although similar methodologies were already applied by previous studies to other winemaking regions, allowing the identification of the existing terroirs (Douglas et al., 2001; Nunez et al., 2011; Priori et al., 2014; Costantini et al., 2016; Moral et al., 2016), an integration of all these factors was still incipient. These interactions may allow identifying the different environmental processes that account 
for the winemaking quality potential of the different zones in the DDR.

The economic value of this crop is particularly relevant for the Portuguese economy. Regarding the size of the country, Portugal has already a relatively large coverage of planted vineyards, even when compared to other food crops (Anderson and Aryal, 2013). Nonetheless, given the increasing demand for DDR wines, including the world-famous Port wine, it is expected that the vineyard area continues growing. The results highlight that areas that are currently devoted to olive trees and pastures tend to have the highest suitability to new vineyard plantations. In fact, the strong relationship between vineyard and olive tree land use is already noticeable in the DDR. The multivariate zoning presented herein was able to clearly reveal this relationship. This assessment provides valuable information to future potential winemaking investors, in selecting new areas for vineyard settlements.

The multivariate zoning of viticultural terroirs provided in the present study may also be of great importance to policymakers and stakeholders operating in the DDR, acting as an additional decision support tool. Currently, in this region, a ranking system for vineyard plots is in force, with a classification scheme ranging from the best sites (class A) to the worst (class F) (Instituto dos Vinhos

\section{REFERENCES}

Agosta E., Canziani P., Cavagnaro M., 2012. Regional climate variability impacts on the annual grape yield in Mendoza, Argentina. J. Appl. Meteorol. Clim., 51, 993-1009.

Alves F., Edlmann M., Costa J., Costa P., Macedo P., Leal da Costa P., Symington C., 2013. Heat requirements and length of phenological stages. Effects of rootstock on red grape varieties at Douro Region. $18^{\circ}$ Internacional Symposium GIESCO, Porto, 7-11 Julho 2013.

Anderson J.D., Jones G.V., Tait A., Hall A., Trought, M.C.T., 2012. Analysis of viticulture region climate structure and suitability in New Zealand. J. Int. Sci. Vigne Vin, 46, 149-165.

Anderson K., Aryal N.R., 2013. Which winegrape varieties are grown where? A global empirical picture. University of Adelaide Press, Australia, 700p.

Bettiga L.J., Smith R., Cahn M., 2012. Evaluation of the impacts of in-row vineyard floor management practices on soil and water erosion, vine growth, and productivity of grapevines. Am. J. Enol. Vitic., 63, 441a-441a.

Bindi M., Fibbi L., Gozzini B., Orlandini S., Miglietta F., 1996. Modelling the impact of future climate scenarios on yield and yield variability of grapevine. Clim. Res., 7, 213-224.

Böhm, J., 2010. Portugal vitícola: o grande livro das castas. C. Ferreira, Lisbon, Portugal, 234 pp.

Camps J.O., Ramos M.C., 2012. Grape harvest and yield responses to inter-annual changes in temperature and precipitation in an area do Douro e Porto - IVDP). This ranking system may also be revised based on the current findings. In addition, taking into account the most recent climate change projections for the region (Fraga et al., 2016b; Santos et al., 2017), this ranking may require substantial adaptations in the future. Lastly, the present study can also be used as an archetypal methodology that can be applied to other winemaking regions in the country and even worldwide.

\section{ACKNOWLEDGMENTS}

This work was supported by: the ModelVitiDouro project (PA 53774), funded by the Agricultural and Rural Development Fund (EAFRD) and the Portuguese Government (Measure 4.1 - Cooperation for Innovation PRODER Programme - Rural Development Programme); the INNOVINE\&WINE project (NORTE-01-0145-FEDER-000038), cofunded by the European Regional Development Fund through NORTE 2020 Programme; European Investment Funds (FEDER/COMPETE/POCI), POCI-01-0145-FEDER-006958, and Portuguese Foundation for Science and Technology (FCT), UID/AGR/04033/2013. The postdoctoral fellowship (SFRH/BPD/119461/2016) awarded to the leading author is also acknowledged.

of north-east Spain with a Mediterranean climate. Int. J. Biometeorol., 56, 853-64.

Carey V.A., Saayman D., Archer E., Barbeau G., Wallace M., 2008. Viticultural terroirs in Stellenbosch, South Africa. I. The identification of natural terroir units. J. Int. Sci. Vigne Vin, 42, 169183.

Clingeleffer P., 2014. Terroir: The application of an old concept in modern viticulture. In: N.K.V. Alfen (Editor), Encyclopedia of Agriculture and Food Systems. Academic Press, Oxford, pp. 277288.

Costa R., Fraga H., Fernandes P.M., Santos J.A., 2017. Implications of future bioclimatic shifts on Portuguese forests. Reg. Environ. Change, 17, 117-127.

Costantini E.A.C., Lorenzetti R., Malorgio G., 2016. A multivariate approach for the study of environmental drivers of wine economic structure. Land Use Policy, 57, 53-63.

Cunha M., Richter C., 2016. The impact of climate change on the winegrape vineyards of the Portuguese Douro region. Clim. Change, 138, 239-251.

Douglas D., Cliff M.A., Reynolds A.G., 2001. Canadian terroir: characterization of Riesling wines from the Niagara Peninsula. Food Res. Int., 34, 559-563.

EEA, 2002. CORINE Land Cover update, I\&CLC2000 project, Technical Guidelines.

Failla O., Mariani L., Brancadoro L., Minelli R., Scienza A., Murada G., Mancini S., 2004. Spatial distribution of solar radiation 
and its effects on vine phenology and grape ripening in an alpine environment. Am. J. Enol. Vitic., 55, 128-138.

Fan Y., Li H., Miguez-Macho G., 2013. Global patterns of groundwater table depth. Science, N.Y., 339, 940-943.

FAO/IIASA/ISRIC/ISSCAS/JRC, 2012. Harmonized World Soil Database (version 1.2). FAO, Rome, Italy and IIASA, Laxenburg, Austria.

Fraga H., Amraoui M., Malheiro A.C., Moutinho-Pereira J., EirasDias J., Silvestre J., Santos J.A., 2014a. Examining the relationship between the Enhanced Vegetation Index and grapevine phenology. Eur. J. Remote Sens., 47, 753-771.

Fraga H., Malheiro A.C., Moutinho-Pereira J., Jones G.V., Alves F., Pinto J.G., Santos J.A., 2014b. Very high resolution bioclimatic zoning of Portuguese wine regions: present and future scenarios. Reg. Environ. Change, 14, 295-306.

Fraga H., Costa R., Moutinho-Pereira J., Correia C.M., Dinis L.-T., Gonçalves I., Silvestre J., Eiras-Dias J., Malheiro A.C., Santos J.A., 2015. Modeling phenology, water status, and yield components of three Portuguese grapevines using the STICS crop model. Am. J. Enol. Vitic., 66, 482-491.

Fraga H., García de Cortázar Atauri I., Malheiro A.C., Santos J.A., 2016a. Modelling climate change impacts on viticultural yield, phenology and stress conditions in Europe. Global Change Biol., 22, doi:10.1111/gcb.13382.

Fraga H., Santos J.A, Moutinho-Pereira J., Carlos C., Silvestre J., Eiras-Dias J., Mota T., Malheiro A.C., 2016b. Statistical modelling of grapevine phenology in Portuguese wine regions: observed trends and climate change projections. J. Agric. Sci., 154, 795-811.

Fraga H., Santos J.A., 2017. Daily prediction of seasonal grapevine production in the Douro wine region based on favourable meteorological conditions. Aust. J. Grape Wine R., 23, 296-304.

Fraga H., García de Cortázar Ataur, I., Santos J.A., 2018. Viticultural irrigation demands under climate change scenarios in Portugal. Agric. Water Manag., 196, 66-74.

GTOPO30, Global 30 Arc-Second Elevation (GTOPO30), USGS Products. Data available from the U.S. Geological Survey.

Hall A., Jones G.V., 2010. Spatial analysis of climate in winegrapegrowing regions in Australia. Aust. J. Grape Wine R., 16, 389-404.

Harbertson J.F., Keller M., 2012. Rootstock effects on deficitirrigated winegrapes in a dry climate: grape and wine composition. Am. J. Enol. Vitic., 63, 40-48.

Hijmans R.J., Cameron S.E., Parra J.L., Jones P.G., Jarvis A., 2005. Very high resolution interpolated climate surfaces for global land areas. Int. J. Clim., 25, 1965-1978.

Holm A., Burnsid, D., Mitchell A., 1987. The development of a system for monitoring trend in range condition in the arid shrublands of Western Australia. The Rangeland Journal, 9, 14-20.

Huete A., Didan K., Miura T., Rodriguez E.P., Gao X., Ferreira L.G., 2002. Overview of the radiometric and biophysical performance of the MODIS vegetation indices. Remote Sens. Environ., 83, 195-213.

IVV, 2015. Vinhos e aguardentes de Portugal, Anuário 2015. Ministério da Agricultura, do Desenvolvimento Rural e das Pescas: Instituto da Vinha e do Vinho, Lisboa: 236.

Johnson L.F., Bosch D.F., Williams D.C., Lobitz B.M., 2001. Remote sensing of vineyard management zones: Implications for wine quality. Appl. Eng. Agric., 17, 557-560.
Johnson L.F., Roczen D.E., Youkhana S.K., Nemani R.R., Bosch D.F., 2003. Mapping vineyard leaf area with multispectral satellite imagery. Comput. Electron. Agric., 38, 33-44.

Jones G.V., Davis R.E., 2000. Climate influences on grapevine phenology, grape composition, and wine production and quality for Bordeaux, France. Am. J. Enol. Vitic., 51, 249-261.

Jones G.V., 2006. Climate and terroir: Impacts of climate variability and change on wine in fine wine and terroir - The geoscience perspective. Macqueen, R.W., and Meinert, L.D., (eds.). Geoscience Canada, Geological Association of Canada, Newfoundland, Canada

Jones G.V., Duff A.A., Hall A., Myers J.W., 2010. Spatial analysis of climate in winegrape growing regions in the Western United States. Am. J. Enol. Vitic., 61, 313-326.

Jones G.V., Alves F., 2012. Impact of climate change on wine production: a global overview and regional assessment in the Douro Valley of Portugal. Int. J. of Global Warming, 4, 383-406.

Judit G., Gabor Z., Adam D., Tamas V., Gyorgy B., 2011. Comparison of three soil management methods in the Tokaj wine region. Mitt Klosterneuburg, 61, 187-195.

Keller M., 2010. The science of grapevines: Anatomy and physiology. Elsevier, Inc. 400pp.

Kizildeniz T., Mekni I., Santesteban H., Pascual I., Morales F., Irigoyen J.J., 2015. Effects of climate change including elevated CO2 concentration, temperature and water deficit on growth, water status, and yield quality of grapevine (Vitis vinifera L.) cultivars. Agric. Water Manag., 159, 155-164.

Lopes J., Eiras-Dias J.E., Abreu F., Climaco P., Cunha J.P., Silvestre J., 2008. Thermal requirements, duration and precocity of phenological stages of grapevine cultivars of the Portuguese collection. Ciência Téc. Vitiv., 23, 61-71.

Mackenzie D.E., Christy A.G., 2005. The role of soil chemistry in wine grape quality and sustainable soil management in vineyards. Wat. Sci. Technol., 51, 27-37.

Magalhães N., 2008. Tratado de viticultura: a videira, a vinha e o terroir. Chaves Ferreira, Lisboa, Portugal, 605 pp.

Moral F.J., Rebollo F.J., Paniagua L.L., Garcia-Martin A., 2016. A GIS-based multivariate clustering for characterization and ecoregion mapping from a viticultural perspective. Span. J. Agric. Res., 14.

Morlat R., Jacquet A., 2003. Grapevine root system and soil characteristics in a vineyard maintained long-term with or without interrow sward. Am. J. Enol. Vitic., 54, 1-7.

Nascimbene J., Marini L., Ivan D., Zottini M., 2013. Management intensity and topography determined plant diversity in vineyards. Plos One, 8, 7.

Nunez J.C.H., Ramazzotti S., Stagnari F., Pisante M., 2011. A multivariate clustering approach for characterization of the Montepulciano d'Abruzzo Colline Teramane area. Am. J. Enol. Vitic. 62, 239-244.

OIV, 2010. Resolution OIV/VITI 333/2010, Definition of vitivinicultural “TERROIR”, Tbilisi, 25th June 2010

Oliveira C., Barbosa A., Ferreira A.C., Guerra J., De Pinho P.G., 2005. Douro grape characterization: Carotenoid profile in grapes related to aromatic compounds in wine. Am. J. Enol. Vitic., 56 306a-307a.

Pavlousek P., 2011. Evaluation of drought tolerance of new grapevine rootstock hybrids. J. Environ. Biol., 32, 543-549. 
Permanhani M., Costa J.M., Conceição M.A.F., de Souza R.T., Vasconcellos M.A.S., Chaves M.M., 2016. Deficit irrigation in table grape: eco-physiological basis and potential use to save water and improve quality. Theor. Exp. Plant Physiol., 28, 85-108.

Priori S., Barbetti R., L'Abate G., Bucelli P., Storchi P., Costantini E.A.C., 2014. Natural terroir units, Siena province, Tuscany. J. Maps, 10, 466-477.

Renouf V., Tregoat O., Roby J.P., Van Leeuwen C., 2010. Soils, rootstocks and grapevine varieties in prestigious Bordeaux vineyards and their impact on yield and quality. J. Int. Sci. Vigne Vin, 44, 127-134.

Rivas-Martínez, S., Rivas-Saenz S., 2011. Worldwide bioclimatic classification system. Phytosociological Research Center, Spain, http://www.globalbioclimatics.org.

Roderick M., Smith R., Lodwick G., 1996. Calibrating long-term AVHRR-derived NDVI imagery. Remote Sens. Environ., 58, 1-12.

Sadras V.O., Moran M.A., 2013. Nonlinear effects of elevated temperature on grapevine phenology. Agric. For. Meteorol., 173, 107-115.

Santos, J.A., Belo-Pereira, M., Fraga, H., Pinto, J.G., 2016. Understanding climate change projections for precipitation over western Europe with a weather typing approach. J. Geophys. Res. Atmos., 121, 1170-1189.

Santos, J.A., Costa, R., Fraga, H., 2017. Climate change impacts on thermal growing conditions of main fruit species in Portugal. Clim. Change, 140, 273-286.

Storchi, P., Costantini, E.A.C., Bucelli, P., 2005. The influence of climate and soil on viticultural and enological parameters of 'Sangiovese' grapevines under non-irrigated conditions. Acta Hortic., 689, 333-340.

Taylor, J.A., 2004. Digital terroirs and precision viticulture: Investigations into the application of information technology in
Australian vineyards. PhD Thesis. The University of Sydney. Sydney, Australia.

Tonietto, J., 1999. Les macroclimats viticoles mondiaux et l'influence du mésoclimat sur la typicité de la Syrah et du Muscat de Hambourg dans le sud de la France: méthodologie de caractérisation. PhD Dissertation, 233p, Ecole Nationale Supérieure Agronomique, Montpellier, France.

Tonietto J., Carbonneau A., 2004. A multicriteria climatic classification system for grape-growing regions worldwide. Agric. For. Meteorol., 124, 81-97.

Tramontini S., van Leeuwen C., Domec J.C., Destrac-Irvine A., Basteau C., Vitali M., Mosbach-Schulz O., Lovisolo C., 2013. Impact of soil texture and water availability on the hydraulic control of plant and grape-berry development. Pl. Soil, 368, 215230.

Usha K., Singh B., 2013. Potential applications of remote sensing in horticulture-A review. Sci. hort., 153, 71-83.

van Leeuwen C., Friant P., Choné X., Tregoat O., Koundouras S., Dubordieu D., 2004. Influence of climate, soil, and cultivar on terroir. Am. J. Enol. Vitic., 55, 207-217.

Webb L.B., Whetton P.H., Bhend J., Darbyshire R., Briggs P.R., Barlow E.W.R., 2012. Earlier wine-grape ripening driven by climatic warming and drying and management practices. Nat. Clim. Change, 2, 259-264.

Winkler A.J., 1974. General viticulture. University of California Press, California, USA.

Yau I.H., Davenport J.R., Rupp, R.A., 2013. Characterizing inland Pacific Northwest American viticultural areas with geospatial data. Plos One, 8. 